\title{
Lithic Morphological Organisation: Gahagan Bifaces from the Southern Caddo Area
}

\author{
Robert Z. Selden, Jr. ${ }^{a, b, c^{*}}$, John E. Dockall ${ }^{d, e}$, and Harry J. Shafer ${ }^{\mathrm{f}}$ \\ ${ }^{a}$ Center for Regional Heritage Research, Stephen F. Austin State University, United States \\ ${ }^{b}$ Cultural Heritage Department, Jean Monnet University, France \\ ${ }^{c}$ ORCID ID 0000-0002-1789-8449 \\ ${ }^{d}$ Prewitt and Associates, Inc., United States \\ ${ }^{e}$ ORCID ID 0000-0002-0940-7144 \\ ${ }^{f}$ Department of Anthropology, Texas AछM University, United States
}

\begin{abstract}
This analysis of Gahagan biface morphology enlists the three largest samples of Gahagan bifaces, to include that of the type site (Gahagan Mound) as well as the Mounds Plantation and George C. Davis sites. Results indicate a significant difference in Gahagan biface morphology at the Mounds Plantation site when compared with Gahagan bifaces from the Gahagan Mound and George C. Davis sites. Tests for allometry and asymmetry were not significant. The test of morphological disparity indicates that Gahagan bifaces produced at the Mounds Plantation site occupy a more restricted range of morphospace than those produced at Gahagan Mound, providing indirect evidence for standardisation and diversity in Caddo biface production. While the sample includes a wide range of morphological variability, the test of morphological integration indicates that Gahagan bifaces are significantly integrated, meaning that those traits used to characterise their shape (blade and base) vary in a coordinated manner. These results articulate with a shift in Caddo bottle morphology over the same geography, potentially indicating two previously unrecognised and morphologically-distinct lithic and ceramic production areas.
\end{abstract}

Keywords: American Southeast, Caddo, 3D, geometric morphometrics, morphological integration, morphological disparity, virtual archaeology

\footnotetext{
${ }^{*}$ Corresponding author, Robert Z. Selden, Jr. (zselden@sfasu.edu)
} 


\section{Gahagan bifaces}

Newell \& Krieger $(1949,173-174)$ originally termed the large thin bifaces from tomb contexts at the George C. Davis site to be similar in form, but not technology, to the Copena points discovered in northern Alabama and described

s by Webb \& DeJarnette (1942, 301-306). The chronological placement of Gahagan bifaces is Late Prehistoric with a distribution that includes central, eastcentral, and east Texas with a limited presence in south Texas and Louisiana (Turner et al., 2011, 230). Previous mortuary occurrences of Gahagan bifaces have been reported from Gahagan Mound (Webb \& Dodd, 1939) and Mounds 10 Plantation (Moore, 1912) in northwestern Louisiana (Figure 1). Clarence H. Webb later suggested Gahagan as a typological term to replace Copena at the 1970 Caddo Conference (Shafer, 1973, 229); however, it was not until 2006 that a morphological and technological description was advanced (Shafer, 2006, 22):

Gahagan bases are either slightly concave or straight, and the lateral edges are slightly recurved, contracting slightly below the base and reaching maximum width about mid-length on the less-reduced examples. Lateral edges are finished and retouched by fine pressure flaking. Thinning flakes expand out from the platform and terminate near the middle of the blade rather than carrying across, indicating well-controlled thinning skill. Cross sections are faintly lenticular to almost flat. Retouching reduces the size and curvature of the blade to the extent that the blades may become almost triangular but usually retain the recurved blade form. Bevelling along the lower part of the left edge is a rare, uncharacteristic method of resharpening. The knives may display moderate to extensive use wear in the form of microflake damage or 'nicking' and edge abrasion. The overall size depends largely on the degree of retouch.

Researchers initially considered the majority of Gahagan bifaces to be man- 


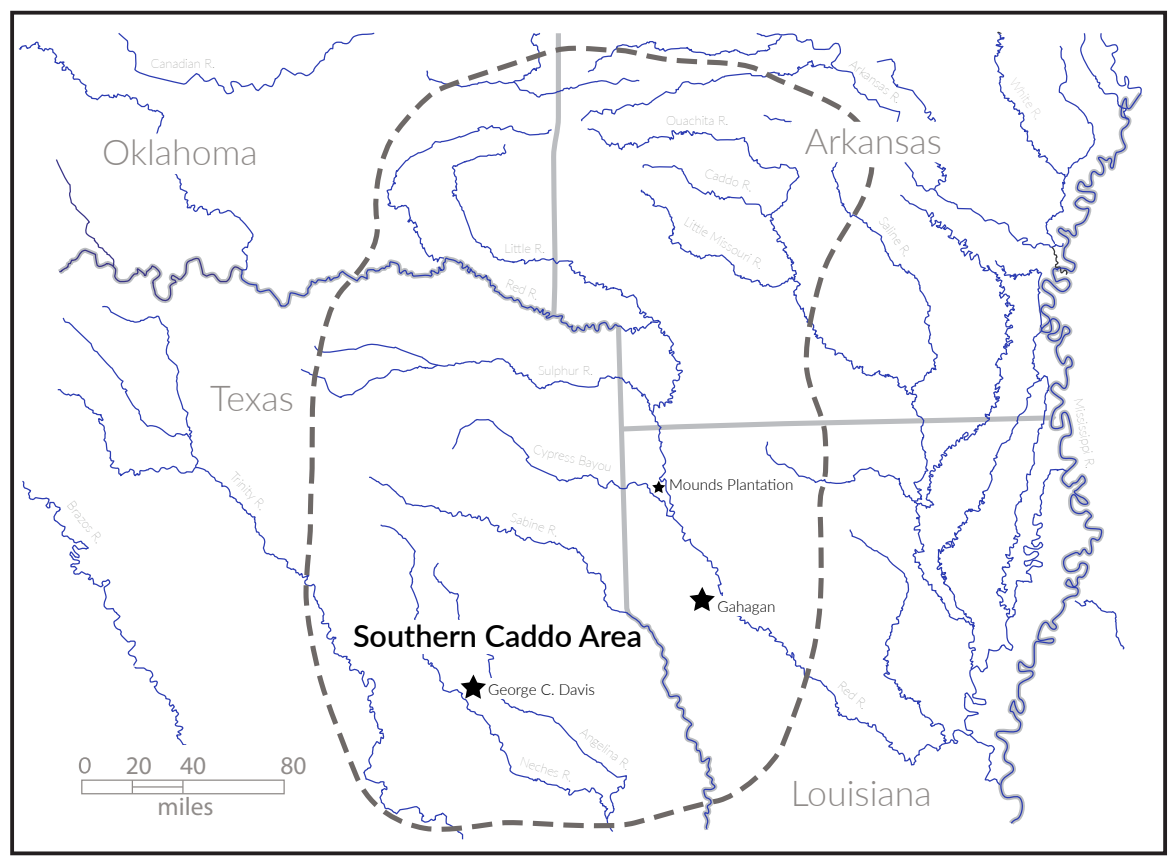

Figure 1: Location of the Gahagan Mound, Mounds Plantation, and George C. Davis sites in the Southern Caddo Area.

ufactured of Edwards chert but subsequent studies of those bifaces from Davis (Shafer, 2006), Mounds Plantation (Webb \& McKinney, 1975) and other locations (Banks \& Winters, 1975) have documented a surprising diversity of raw materials in addition to Edwards. Other raw materials represented include chert sources in the Kiamichi Mountains of southeastern Oklahoma, and Woodford, Battiest, Big Fork and Ogallala cherts (Banks \& Winters, 1975).

Given the significance of blade and base shape to the definition of the Gahagan type, only intact or reconstructed specimens were used in this analysis (Table 1). While comparisons and reference to these three assemblages of Gahagan bifaces occur in the gray literature (Denton, 1983; Gadus et al., 2006; McClurkan, 1968; Quigg et al., 2014), these specimens have not previously been aggregated for a comprehensive morphological analysis. Preliminary observations point to significant morphological differences between Gahagan bifaces 
recovered from Mounds Plantation and those found at the Gahagan Mound and George C. Davis sites. Given the importance of these bifaces to defining components of Caddo sites that may articulate with Formative or Early Caddo 45 occupations, additional tests for morphological disparity, and morphological integration of the base and blade were used to further expound upon the quiddity of the Gahagan biface type.

Table 1: Sample of Gahagan bifaces included in the study.

\begin{tabular}{|c|c|c|c|c|}
\hline Specimen & Trinomial & Context & Site Name & Repository \\
\hline 3Ba90 & 16CD12 & Burial Pit 1 & Mounds Plantation & LSEM \\
\hline 3Bb1 & 16CD12 & Burial Pit 2 & Mounds Plantation & LSEM \\
\hline 3Bb3 & 16CD12 & Burial Pit 2 & Mounds Plantation & LSEM \\
\hline $3 \mathrm{Bb} 4$ & 16CD12 & Burial Pit 2 & Mounds Plantation & LSEM \\
\hline 3Bb5 & 16CD12 & Burial Pit 2 & Mounds Plantation & LSEM \\
\hline 3Bb6 & $16 \mathrm{CD} 12$ & Burial Pit 2 & Mounds Plantation & LSEM \\
\hline $3 \mathrm{Bb} 7$ & 16CD12 & Burial Pit 2 & Mounds Plantation & LSEM \\
\hline 3Bb8 & $16 \mathrm{CD} 12$ & Burial Pit 5 & Mounds Plantation & LSEM \\
\hline BlkThn & 16CD12 & Burial Pit 2 & Mounds Plantation & LSEM \\
\hline Case2LG & 16CD12 & Burial Pit 2 & Mounds Plantation & LSEM \\
\hline Case2SM & $16 \mathrm{CD} 12$ & Burial Pit 5 & Mounds Plantation & LSEM \\
\hline LGGray & 16CD12 & Burial Pit 8 & Mounds Plantation & LSEM \\
\hline 489 & $16 \mathrm{RR} 1$ & Burial Pit 2 & Gahagan Mound & LSEM \\
\hline 490 & $16 \mathrm{RR} 1$ & Burial Pit 2 & Gahagan Mound & LSEM \\
\hline 532 & $16 \mathrm{RR} 1$ & Burial Pit 2 & Gahagan Mound & LSEM \\
\hline 533 & $16 \mathrm{RR} 1$ & Burial Pit 2 & Gahagan Mound & LSEM \\
\hline 541 & $16 \mathrm{RR} 1$ & Burial Pit 2 & Gahagan Mound & LSEM \\
\hline 542 & $16 \mathrm{RR} 1$ & Burial Pit 2 & Gahagan Mound & LSEM \\
\hline 543 & $16 \mathrm{RR} 1$ & Burial Pit 2 & Gahagan Mound & LSEM \\
\hline 544 & $16 \mathrm{RR} 1$ & Burial Pit 2 & Gahagan Mound & LSEM \\
\hline 545 & $16 \mathrm{RR} 1$ & Burial Pit 2 & Gahagan Mound & LSEM \\
\hline 546 & $16 \mathrm{RR} 1$ & Burial Pit 2 & Gahagan Mound & LSEM \\
\hline 547 & 16RR1 & Burial Pit 2 & Gahagan Mound & LSEM \\
\hline 548 & $16 \mathrm{RR} 1$ & Burial Pit 2 & Gahagan Mound & LSEM \\
\hline 549 & 16RR1 & Burial Pit 2 & Gahagan Mound & LSEM \\
\hline 550 & 16RR1 & Burial Pit 2 & Gahagan Mound & LSEM \\
\hline
\end{tabular}

Continued on next page 
Table 1 - continued from previous page

\begin{tabular}{|c|c|c|c|c|}
\hline Specimen & Trinomial & Context & Site Name & Repository \\
\hline 551 & 16RR1 & Burial Pit 2 & Gahagan Mound & WMNSU \\
\hline 569 & 16RR1 & Burial Pit 2 & Gahagan Mound & LSEM \\
\hline 593 & 16RR1 & Burial Pit 3 & Gahagan Mound & LSEM \\
\hline 605 & 16RR1 & Burial Pit 3 & Gahagan Mound & LSEM \\
\hline 606 & 16RR1 & Burial Pit 3 & Gahagan Mound & LSEM \\
\hline 607 & 16RR1 & Burial Pit 3 & Gahagan Mound & LSEM \\
\hline 608 & $16 \mathrm{RR} 1$ & Burial Pit 3 & Gahagan Mound & LSEM \\
\hline 609 & 16RR1 & Burial Pit 3 & Gahagan Mound & LSEM \\
\hline 610 & 16RR1 & Burial Pit 3 & Gahagan Mound & LSEM \\
\hline 611 & 16RR1 & Burial Pit 3 & Gahagan Mound & LSEM \\
\hline 612 & $16 \mathrm{RR} 1$ & Burial Pit 3 & Gahagan Mound & LSEM \\
\hline 613 & 16RR1 & Burial Pit 3 & Gahagan Mound & LSEM \\
\hline 614 & $16 \mathrm{RR} 1$ & Burial Pit 3 & Gahagan Mound & LSEM \\
\hline 622 & 16RR1 & Burial Pit 3 & Gahagan Mound & LSEM \\
\hline 666 & 16RR1 & Burial Pit 3 & Gahagan Mound & LSEM \\
\hline ET221-993 & 41CE19 & $6 \mathrm{~L} 3$ & George C. Davis & TARL \\
\hline ET221-1016 & 41CE19 & F3 & George C. Davis & TARL \\
\hline ET221-1260A & 41CE19 & $21 \mathrm{R} 14$ & George C. Davis & TARL \\
\hline $4078-8$ & 41CE19 & F134 & George C. Davis & TARL \\
\hline $4078-9$ & 41CE19 & F134 & George C. Davis & TARL \\
\hline $4078-11$ & 41CE19 & F134 & George C. Davis & TARL \\
\hline $4078-12$ & 41CE19 & F134 & George C. Davis & TARL \\
\hline $4078-13$ & 41CE19 & F134 & George C. Davis & TARL \\
\hline $4078-14$ & 41CE19 & F134 & George C. Davis & TARL \\
\hline 4078-14B & 41CE19 & F134 & George C. Davis & TARL \\
\hline $4078-22$ & 41CE19 & F134 & George C. Davis & TARL \\
\hline $4078-30$ & 41CE19 & F134 & George C. Davis & TARL \\
\hline $4078-32$ & 41CE19 & F134 & George C. Davis & TARL \\
\hline $4078-45$ & 41CE19 & F134 & George C. Davis & TARL \\
\hline $4078-72$ & 41CE19 & F134 & George C. Davis & TARL \\
\hline $424-33$ & 41CE19 & F119 & George C. Davis & TARL \\
\hline $424-39$ & 41CE19 & F119 & George C. Davis & TARL \\
\hline $424-40$ & 41CE19 & F119 & George C. Davis & TARL \\
\hline $424-41$ & 41CE19 & F119 & George C. Davis & TARL \\
\hline $424-50$ & 41CE19 & F119 & George C. Davis & TARL \\
\hline
\end{tabular}

Continued on next page 
Table 1 - continued from previous page

\begin{tabular}{lcccc}
\hline Specimen & Trinomial & Context & Site Name & Repository \\
\hline $424-53$ & 41 CE19 & F119 & George C. Davis & TARL \\
$424-133$ & 41 CE19 & F119 & George C. Davis & TARL \\
$424-169$ & 41 CE19 & F119 & George C. Davis & TARL \\
$424-218$ & 41 CE19 & F119 & George C. Davis & TARL \\
$424-221$ & 41 CE19 & F119 & George C. Davis & TARL \\
$424-230$ & 41 CE19 & F119 & George C. Davis & TARL \\
$463-1$ & 41 CE19 & F119 & George C. Davis & TARL \\
$463-16$ & 41 CE19 & F119 & George C. Davis & TARL \\
$463-23$ & 41 CE19 & F119 & George C. Davis & TARL \\
\hline
\end{tabular}

LSEM, Louisiana State Exhibit Museum; WMNSU, Williamson Museum at Northwestern State University; TARL, Texas Archeological Research Laboratory.

\section{Geometric morphometric analyses of stone tools}

Analyses of lithic shape are neither new or novel, and it is not surprising that geometric morphometrics (GM) (sensu Corti (1993)) has captivated analysts of material culture due to the substantive contribution of morphology to lithic typologies (Fox, 2015; Thulman, 2012; Wilczek et al., 2015). The first application

55 of GM to archaeologically-recovered artefacts was an analysis of irregular shapes by elliptic Fourier analysis (EFA) (Gero \& Mazzullo, 1984), and the adoption of the method by the archaeological community has continued.

EFA has been increasingly employed in lithic analyses, where analysts continue are developing novel approaches that advance archaeological applications

6o (Cardillo, 2010; Fox, 2015; Ioviţă, 2009, 2010, 2011; Ioviţă \& McPherron, 2011; Smith et al., 2014; Gingerich et al., 2014; Sholts et al., 2012; Wilczek et al., 2015). Numerous creative research designs have also been presented that address some of the very real challenges associated with the oft-fractured and incomplete specimens abundant in the archaeological record (Byrne et al., 2016;

65 Rezek et al., 2011; Smith, 2010; Smith \& DeWitt, 2016). This approach is particularly useful in instances where homologous landmarks cannot be readily 
identified; for instance, in cases where both lanceolate and stemmed projectile points are employed in the same analysis.

Landmark-based approaches, like the one applied here, articulate with the rise of the Procrustes paradigm (Adams et al., 2013, 8), which have proven utility in archaeological application. This includes a 2D study of blade shape differences in Paleoindian projectile point types where a novel approach to investigating allometry was applied through the use of median point area and size grades to compare shape and size distributions, demonstrating that it is possible to discriminate between some types based upon blade shape "independent of allometry, raw material quality, and resharpening effects" (Buchanan \& Collard, 2010, 357), thus representing a rejection of the reduction thesis (Shott, 2005). Charlin \& González-José (2012) demonstrated that while reduction is important, it has a greater effect on shape than on size; an observation that

so is more apparent on blades than on bases, concluding that the two point types used in their study could be successfully segregated despite reduction. Similarly, Thulman (2012) analysed three Paleoindian projectile points from Florida and found that the types used in his study did not represent continuous variation; rather, they are representative of three discrete groups.

85 Like those studies mentioned above, this analysis enlists a landmark-based approach aimed at capitalising upon the variability that occurs along a single plane (widest biface edge); however, 3D data were required to consistently identify the widest edge. Procrustes ANOVAs were used to test whether the intra-type morphology of Gahagan bifaces varies by size and site, a test of morphological disparity to determine relative standardisation and diversity in the sample, and a test of morphological integration to determine whether biface blade and base shapes covary. Additionally, a variety of landmark and semilandmark configurations are in development that will allow for a more robust analysis of 3D morphology associated with specific elements of Gahagan biface 95 morphology. 


\section{Methods}

Each of the Gahagan bifaces was scanned with a Creaform GoSCAN 20 at a $0.3 \mathrm{~mm}$ resolution in VXelements. Scanner calibration was optimised prior to each scan with positioning targets required for increased accuracy and shutter

C. Davis site (Figure 2) that occurs at variable thicknesses. Shafer $(1973,228)$ posits that this residue potentially represents the remains of a sheath. While an interesting aside, the residue does pose a problem for an analysis of 3D geometry. The initial research design (3D) was thus revisited, leading to a reconfiguration configuration similar to that used by Buchanan \& Collard (2010, Figure 2), Buchanan et al. (2011, Figure 2), and Ragan \& Buchanan (2018, Figure 1). The residue does not occur on all of the George C. Davis specimens, and none of the Gahagan bifaces from the Mounds Plantation or Gahagan Mound sites include a similar residue on their surfaces, making it possible to compare a greater range of surface morphology between those samples. While beyond the scope of this present study, that is an avenue of inquiry worth pursuing should differences in Gahagan biface shape be found to differ among the three sites. 


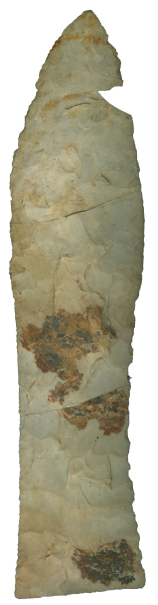

a

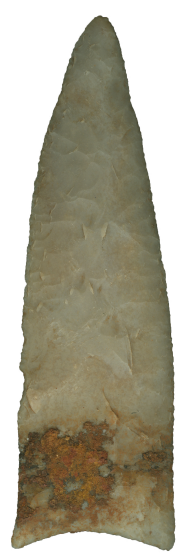

b

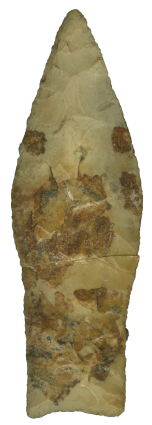

C

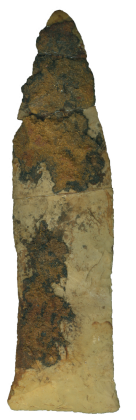

d

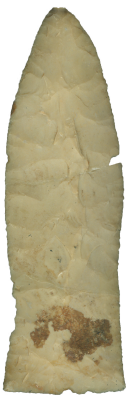

e

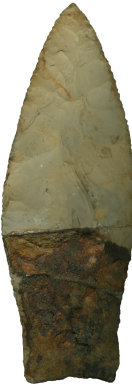

f

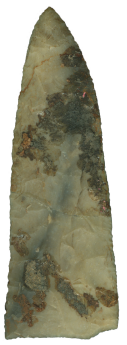

g

Figure 2: Residue adhering to Gahagan bifaces from Feature 134 at the George C. Davis site; a, 4078-8; b, 4078-9; c, 4078-11; d, 4078-13; e, 4078-72; f, 4078-14B; and g, 4078-14.

\subsection{Alignment and reference geometry} point, a mesh sketch was generated using the planar method-employing the plane located at the base of the biface as the base plane - to sketch a circle around the biface from the top view where the whole of the biface profile was 

the biface, and the accuracy analyzer was used to identify the point on the biface with the lowest deviation from the extruded surface. A plane (MPlane) was then inserted coplanar to the vector and oriented to the widest point, thus bisecting the biface at the location of the widest profile.

Using the MPlane as the basis for a third sketch, a spline was populated along the entirety of the silhouetted profile, and split at the location of each landmark (Table 2). Four splits were added that include the tip, juncture of the blade/base (widest profile), centre base, and opposing blade/base. Those landmark locations identified at the two points of highest curvature enlist the curvature function in Dx, and do not represent arbitrary locations.

Table 2: Landmarks used in the analysis.

\begin{tabular}{lcl}
\hline Landmark & Location & Definition \\
\hline Point01 & Tip & Horizontal tangent \\
Point20 & Blade/Base & Point of highest curvature on widest side of biface \\
Point24 & CentreBase & Intersection of vector and external surface of the 3D mesh \\
Point28 & Blade/Base & Point of highest curvature \\
\hline
\end{tabular}

Two specimens in the George C. Davis sample (4078-8 and 4078-72), both from Feature 134, are missing small sections of their lateral edges (Figure 2a, e). For the purpose of the GM analysis, these two areas were modelled, where the spline was cut behind the area of highest curvature above and below the missing piece, and a line was inserted to connect the lateral edge above and below the missing piece. This ensures that the spline provides a model that is closer to the (assumed) original intent of the maker.

Due to the paucity of homologous landmarks or points of morphological correspondence on stone artefacts (Lycett, 2009, 81), reference geometry was constructed around each specimen in a manner that yields a replicable configuration of three landmarks, and 43 equidistant semilandmarks. Landmarks and semilandmarks were populated along the spline, always beginning on the side of the biface determined to include the widest point. Divisions between each 
section articulate with those of the spline splits, where landmarks were placed at each of the points in Table 2, with a series of equidistant semilandmarks between (18 for each blade section, and three between each of the basal landmarks; Figure 3). This constellation of landmarks and semilandmarks allows for tests of morphological integration between the blade and base as well as a test of directional asymmetry (Bookstein, 1991; Klingenberg \& McIntyre, 1998; Klingenberg et al., 2002; Mardia, 2000).

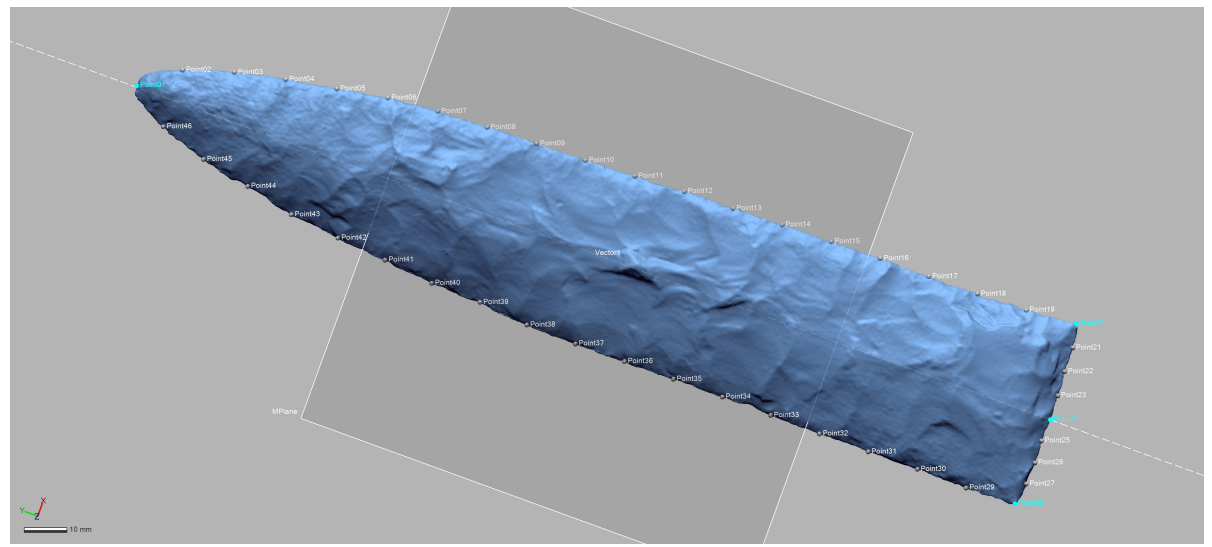

Figure 3: Landmark (blue) and semilandmark (white) placement.

\subsection{Analysis}

Landmarks and equidistant semilandmarks were exported as $\mathrm{x}, \mathrm{y}$, and z coordinate data from Dx. Those data were aligned to a global coordinate system (Kendall, 1981, 1984; Slice, 2001), achieved through generalised Procrustes superimposition (Rohlf \& Slice, 1990) performed in R 3.4.4 (R Core Development Team,, 2017) using the geomorph library v.3.0.5 (Adams et al., 2017; Adams \& Otárola-Castillo, 2013). Procrustes superimposition translates, scales, and rotates the coordinate data to allow for comparisons among objects (Gower, 1975; Rohlf \& Slice, 1990). The geomorph package uses a partial Procrustes superimposition that projects the aligned specimens into tangent space subsequent to alignment in preparation for the use of multivariate methods that assume linear space (Rohlf, 1999; Slice, 2001). 
Principal components analysis (Jolliffe, 2002) was used to visualise shape variation among the bifaces. The shape changes described by each principal mesh (Klingenberg, 2013; Sherratt et al., 2014). A residual randomisation permutation procedure (RRPP; $n=1000$ permutations) was used for all Procrustes ANOVAs (Adams \& Collyer, 2015), which has higher statistical power and a greater ability to identify patterns in the data should they be present (Anderand differs by group (types and sites), Procrustes ANOVAs (Goodall, 1991) were also run that enlist effect-sizes (z-scores) computed as standard deviates of the generated sampling distributions (Collyer et al., 2015).

A Procrustes ANOVA and pairwise test was used to identify sites where biface shapes differ. The pairwise test is conceptually similar to trajectory analysis (Adams \& Collyer, 2007, 2009; Collyer \& Adams, 2007, 2013) in that pairwise statistics are vector lengths between vectors, but differs since a factorial model is not explicitly needed to contrast vectors between point factor levels nested within group factor levels (Adams et al., 2017). Procrustes variance was used to discriminate between groups and compare the amount of shape variation (morphological disparity) across sites (Zelditch et al., 2004), which is estimated as the Procrustes variance using residuals of linear model fit (Adams et al., 2017).

Morphological integration was tested using a two-block partial least-squares 205 (2B-PLS) analysis to evaluate relationships for two (or more) blocks of variables collected from the same specimens (Bookstein et al., 2003; Rohlf \& Corti, 2000; Wold, 1966). Using shape coordinates in all blocks of variables, 2B-PLS can be used to assess morphological integration (Bastir \& Rosas, 2006; Bookstein et al., 2003; Gunz \& Harvati, 2007). This analysis includes blade shape (Block 210 1) and base shape (Block 2), allowing for a test of morphological integration between the blocks. 


\section{Results}

The mean consensus configuration and Procrustes residuals were calculated for each site by means of a generalised Procrustes analysis (GPA) (Mitteroecker \& Gunz, 2009, Figure 3) (Figure 4). This initial view of the dataset demonstrates the degree of variation that occurs at each site and in the combined sample. As an exploratory measure, GM methods - to include GPA - aid in clarifying shape differences associated with each population and in the production of novel a posteriori hypotheses (Mitteroecker \& Gunz, 2009).
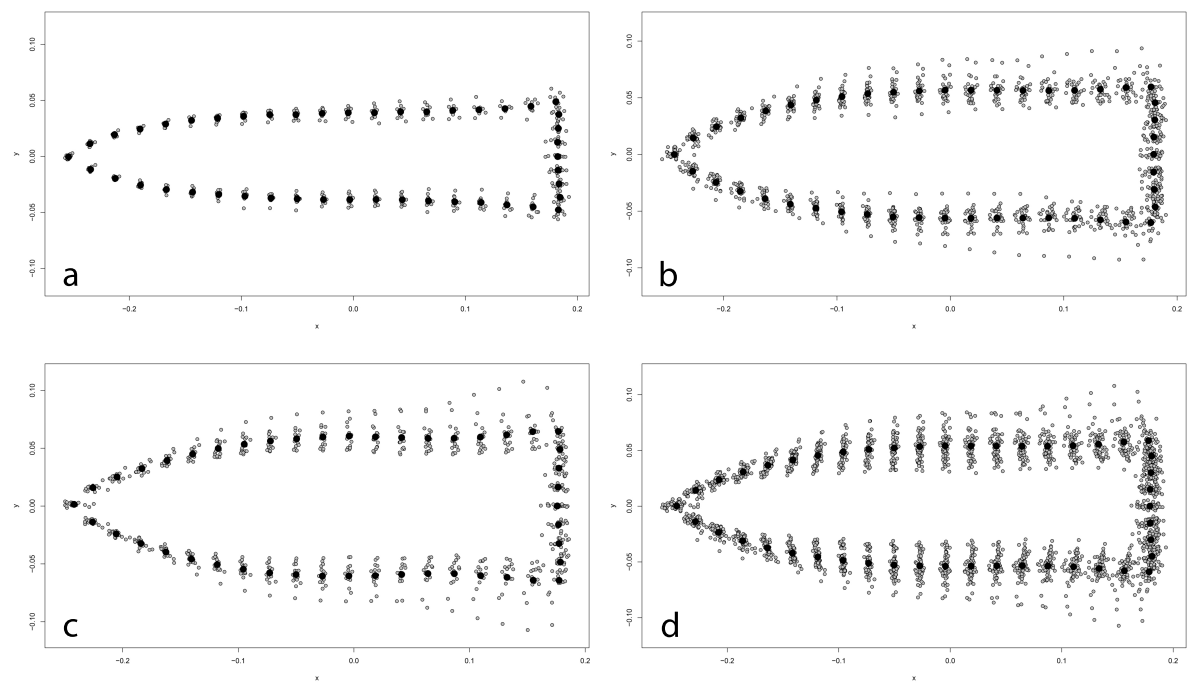

Figure 4: Mean consensus configuration (black) with Procrustes residuals (gray) superimposed by generalised Procrustes analysis for a, Mounds Plantation; b, Gahagan Mound; c, George C. Davis; and d, all specimens.

The mean consensus configuration for the sample from each site points toward a potentially significant difference in Gahagan biface morphology at the Mounds Plantation site. It may also be the case that the Gahagan bifaces produced at Mounds Plantation occupy a smaller range of morphospace than those recovered at Gahagan Mound and George C. Davis. While the mean consensus configurations for Gahagan bifaces from Gahagan Mound and George C. Davis 
do appear to be similar, there are some notable differences. The bifaces from Gahagan Mound generally include less recurve in the blade, and a base that is more convex than that of the bifaces from George C. Davis, where the mean consensus configuration of the base is slightly concave.

Principal components analysis (PCA) was conducted on scaled, translated, and rotated landmarks, and demonstrates that the first two PCs account for 76 ( $\mathrm{PC} 1)$ and nine ( $\mathrm{PC} 2)$ percent of the variation in Gahagan biface shape (Table 3 and Figure 5). Together, PC1 and PC2 account for over 86 percent of shape variation for Gahagan bifaces, with each remaining PC representing less than five percent of the variation (Table 3). The first two PCs are plotted in Figure 5, where warp grids represent the shape changes along PC1 and $\mathrm{PC}$. This plot indicates that shape changes associated with PC1 articulate most readily with blades that range from broader at the minimum to narrow at the maximum, and base shapes that range from more concave at the minimum toflat or slightly convex at the maximum. Those shape changes associated with $\mathrm{PC} 2$ are dominated by differences in base shapes that range from narrow at minimum to broad at maximum, and blade shapes that are broader at minimum to narrower at maximum.

A Procrustes ANOVA was then used to test whether there was a significant 245 difference in biface shape by site. Results of the ANOVA indicate a significant difference in biface shape by site $(\mathrm{RRPP}=1000 ; \mathrm{Rsq}=0.33044 ; \operatorname{Pr}(>\mathrm{F})=$ 0.001 ), and a pairwise test of shapes between groups designated by site confirms a significant difference in Gahagan biface shape at the Mounds Plantation site when compared with Gahagan Mound and George C. Davis (Table 4).

The test of morphological disparity indicates that while bifaces at both Gahagan Mound and George C. Davis display a greater range of shape variation among individuals relative to other groups, the Gahagan bifaces from Gahagan Mound occupy a significantly greater range of morphospace than those from Mounds Plantation (Table 5). This indicates that those bifaces at the Gahagan

255 Mound site encompass a greater range of morphological variability than those produced at the Mounds Plantation site, meaning that Caddo makers at the 
Table 3: Results of principal components analysis for first 10 PCs ( $>98$ percent of total variance explained).

\begin{tabular}{llll}
\hline & SD & PVE & CVE \\
\hline PC1 & 0.05939 & 0.76305 & 0.76305 \\
PC2 & 0.02132 & 0.09829 & 0.86135 \\
PC3 & 0.01504 & 0.04891 & 0.91026 \\
PC4 & 0.01041 & 0.02347 & 0.93373 \\
PC5 & 0.009359 & 0.018950 & 0.952680 \\
PC6 & 0.007708 & 0.012850 & 0.965540 \\
PC7 & 0.007231 & 0.011310 & 0.976850 \\
PC8 & 0.004334 & 0.004060 & 0.980910 \\
PC9 & 0.003663 & 0.002900 & 0.983810 \\
PC10 & 0.003434 & 0.002550 & 0.986370 \\
\hline
\end{tabular}

$S D$ - standard deviation; PVE - percentage variance explained; CVE - cumulative variance explained.

Mounds Plantation site were participating in a more morphologically-restricted method of biface manufacture.

A two-block partial least-squares (2B-PLS) analysis was used to test for morphological integration between base and blade shape of the Gahagan biface sample. The results indicate significant morphological integration (1000 random permutations; r-PLS $=0.805 ; \mathrm{P}$-value $=0.001)$, indicating that blade shape and base shape vary in a coordinated manner (Figure 6). In general terms, longer and thinner bifaces were found to articulate with a slightly convex base, while shorter and broader bifaces articulate with a slightly concave base.

A comparison of mean consensus configurations was used to further characterise the intra-site shape variation of Gahagan bifaces from Mounds Plantation, Gahagan Mound, and George C. Davis (Figure 7). While those comparisons visualised in Figure 7a and b were found to represent significant differences in biface morphology, the comparison in Figure $7 \mathrm{c}$ was not. The subsequent test of directional asymmetry yielded results that were not significant. 


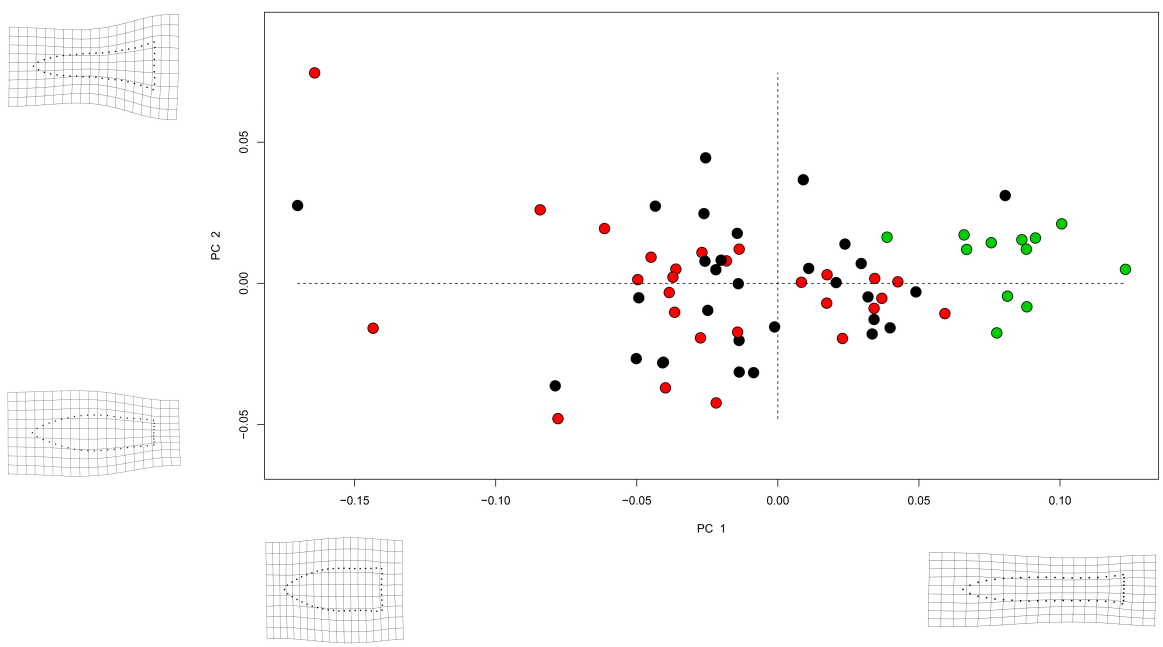

Figure 5: Principal components analysis plot (PC1/PC2) for Gahagan bifaces by site; green, Mounds Plantation; black, Gahagan Mound; red, George C. Davis.

\section{Discussion}

This comparison of the three largest assemblages of Gahagan bifaces from the Southern Caddo Area demonstrates a significant difference in the shape of Plantation differ significantly in shape from the other assemblages (Table 4 
Table 4: P-values, effect sizes, and least-squares mean distance matrix for advanced Procrustes ANOVA and pairwise test $(\mathrm{RRPP}=1000)$ of Gahagan biface shape.

\begin{tabular}{lrrr}
\hline & Gahagan Mound & George C Davis & Mounds Plantation \\
\hline Gahagan Mound & 1.000 & & \\
& 0.0000000 & & \\
George C Davis & $(0.00000000)$ & & \\
& 0.343 & 1.000 & \\
Mounds Plantation & 0.1620967 & 0.0000000 & 1.000 \\
& $(0.01783345)$ & $(0.00000000)$ & 0.000000 \\
& $\mathbf{0 . 0 0 1}$ & $\mathbf{0 . 0 0 1}$ & $(0.00000000)$ \\
\hline
\end{tabular}

Significant differences in bold; effect sizes (z) in italics; least-squares means distance matrix in parentheses.

and Figure 5), and occupy a more restricted range of morphospace than those produced at the type site (Table 5 and Figure 7). Results imply spatial production differences in northern (above the confluence of Cypress Bayou and the Red River) and southern (below) Caddo sites that align with recent findings associated with Hickory Engraved and Smithport Plain Caddo bottles from the same area (Selden Jr., 2018a,b), and also demonstrate that Caddo makers at the Mounds Plantation site were enlisting a more standardised approach to the

Table 5: P-values and pairwise absolute differences between variances for the test of morphological disparity $(\mathrm{RRPP}=1000)$.

\begin{tabular}{lrrr}
\hline & Gahagan Mound & George C Davis & Mounds Plantation \\
\hline Gahagan Mound & 1.000 & & \\
George C Davis & 0.0000000000 & & \\
Mounds Plantation & 0.640 & 1.000 & 1.000 \\
& 0.0007943556 & 0.0000000000 & 0.089 \\
\hline
\end{tabular}

Significant differences in bold; pairwise absolute differences between variances in italics. 


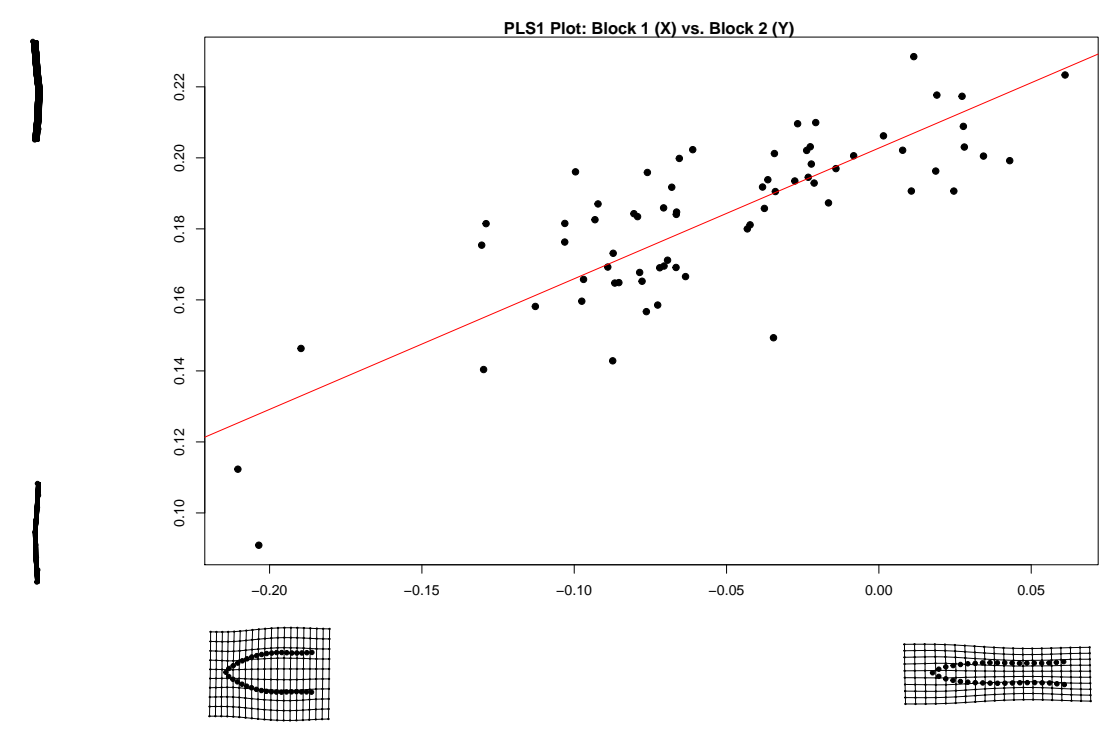

Figure 6: Two-block partial least-squares analysis for morphological integration of blade and base shape with singular warps illustrated.

manufacture of Gahagan bifaces (Table 5). This would similarly imply that Caddo makers at the Gahagan Mound site were producing Gahagan bifaces with a significantly greater range of morphological diversity (Table 5 and Figure 8). However variable, the morphology of Gahagan bifaces is not without pattern, as blade and base shapes can be said to covary throughout the sample (Figure 6). While additional research is warranted, this result implies that retouch of Gahagan bifaces was not arbitrary; rather, it was a practice constrained to a suite of blade and base shapes that vary in a coordinated manner.

"Standardization refers to homogeneity in ... materials, ... shape, and/or decoration" (Costin \& Hagstrum, 1995, 622), while diversity "can be most generally considered as the opposite of standardization" (Rice, 1991, 273). Standardisation is relative (Costin, 2001; Sinopoli, 1988), and seen as a cultural marker that may have utility in a variety of interpretations. Attributes associated with standardisation may prove dynamic, potentially indicating periods of standardised production as well as periods of creativity that more readily articulate with diversity (Kenoyer et al., 1991). In production contexts, standardisation might 


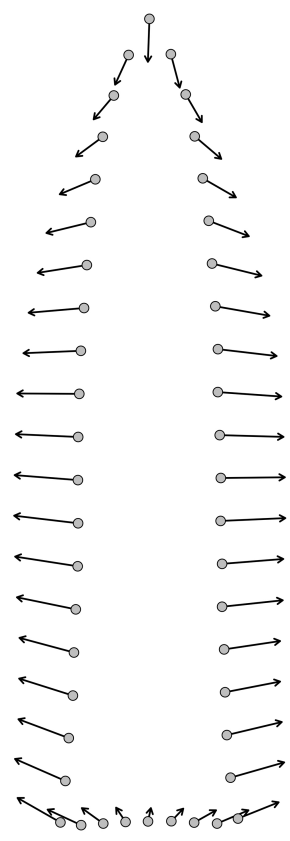

a

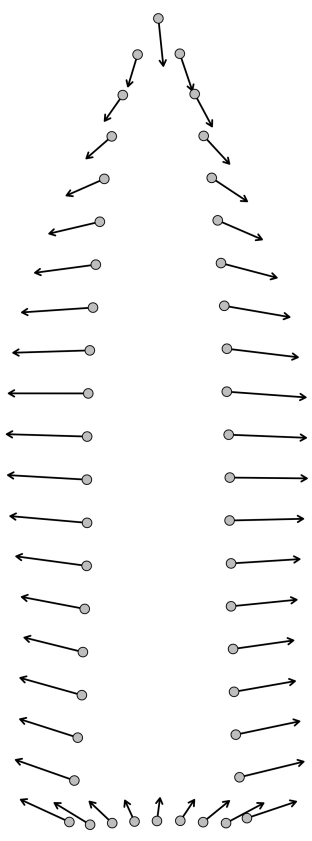

b

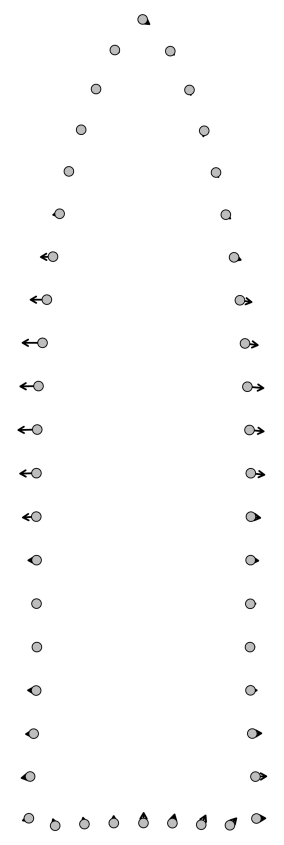

C

Figure 7: Comparison of mean consensus configurations for Gahagan biface shape by site at; a, Mounds Plantation (gray) and Gahagan Mound; b, Mounds Plantation (gray) and George C. Davis; c, Gahagan Mound (gray) and George C. Davis.

be seen as the result of minimised labour costs and improvements in efficiency (Sinopoli, 1988). Both standardisation and diversity have utility in characterising tolerance, where a greater range of shapes may be indicative of a higher tolerance, and where lower tolerances can be demonstrated by production where variation is decreased (Eerkins \& Bettinger, 2001). In this application, those bifaces from the Mounds Plantation site potentially represent production under a model of lower tolerance than those produced at the Gahagan Mound site, where the tolerance to morphological diversity appears higher.

Production activities are more likely to be localised than exchange systems, and are assumed to leave a clearer signature (Costin, 1991); in this case, those variables used in the analysis are the products themselves. The morphological 

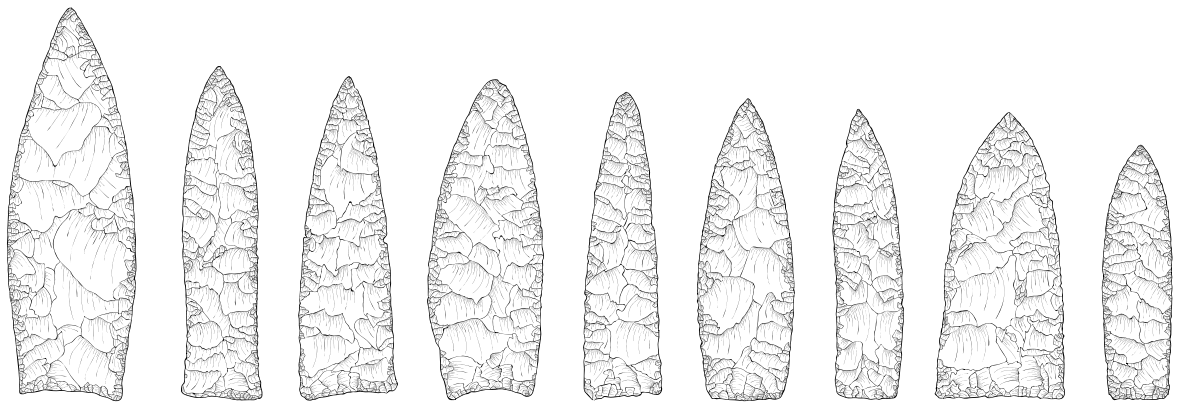

Figure 8: Illustrated sample of Gahagan bifaces from the Gahagan Mound site demonstrating the morphological variation that occurs in Gahagan biface shape at the type site.

attributes are representative of intentional attributes (Costin, 2005) related to morphological characteristics; in this instance, the blade and base of Gahagan bifaces. Dimensional standardisation has utility in identifying the range of variation and the overlap of product morphology within and between communities (Arnold III, 1991). In this study, the relative dimensional standardisation exhibited at the Mounds Plantation site may imply a smaller number of production units (sensu Costin (1991)) contrasted with a larger number of production units at the Gahagan Mound site.

\section{Conclusion}

Through the use of morphological attributes associated with the blade and base shapes of Gahagan bifaces, a significant difference in morphology was found to occur at the Mounds Plantation site, where the range of morphological variation is also significantly more restricted when compared with Gahagan bifaces from the Gahagan Mound site. These results point toward a lower threshold for morphological variability at the Mounds Plantation site, which may indicate a smaller number of production units. While additional research is warranted, these findings articulate with a shift in Hickory Engraved and Smithport Plain bottle morphology over the same (north-south) geography (Selden Jr., 2018a,b), potentially indicating two previously unrecognised and morphologically-distinct 
Caddo lithic and ceramic production areas.

\section{Acknowledgments}

We extend our gratitude to the Caddo Nation of Oklahoma, Northwestern State University (Williamson Museum), the Louisiana State Exhibit Museum, and the Texas Archeological Research Laboratory for the requisite permissions and access needed to generate the 3D scans of the Gahagan bifaces. Thanks also to Dean C. Adams, Emma Sherratt, Timothy K. Perttula, Jeffrey R. Girard, Hiram F. (Pete) Gregory, and Kersten Bergstrom for their constructive criticisms, comments, and suggestions throughout the development of this research design, and to the anonymous reviewers for their comments and constructive criticisms, which further improved this manuscript. Components of this analytical work flow were developed and funded by a grant (P14AP00138) to RZS from the National Center for Preservation Technology and Training.

\section{References Cited}

Adams, D. C., \& Collyer, M. L. (2007). Analysis of Character Divergence along Environmental Gradients and other Covariates. Evolution, 61, 510-5. URL: https://www.ncbi.nlm.nih.gov/pubmed/17348916. doi:10.1111/j . $1558-5646.2007 .00063 . x$.

Adams, D. C., \& Collyer, M. L. (2009). A General Framework for the Analysis of Phenotypic Trajectories in Evolutionary Studies. Evolution, 63, 114354. URL: http://www.ncbi.nlm.nih.gov/pubmed/19210539. doi:10.1111/ j.1558-5646.2009.00649.x.

Adams, D. C., \& Collyer, M. L. (2015). Permutation Tests for Phylogenetic Comparative Analyses of High-Dimensional Shape Data: What you Shuffle Matters. Evolution, 69, 823-9. URL: http://www.ncbi.nlm.nih.gov/ pubmed/25641367. doi:10.1111/evo.12596. 
Adams, D. C., Collyer, M. L., Kaliontzopoulou, A., \& Sherratt, E. (2017). Package 'geomorph': Geometric Morphometric Analyses of 2D/3D Landmark Data. R package version 3.0.5. URL: http://geomorphr.github.io/ geomorph/.

Adams, D. C., \& Otárola-Castillo, E. (2013). geomorph: An R Package for the Collection and Analysis of Geometric Morphometric Shape Data. Methods in Ecology and Evolution, 4, 393-399. doi:10.1111/2041-210x.12035.

Adams, D. C., Rohlf, F. J., \& Slice, D. E. (2013). A Field Comes of Age: 375 Geometric Morphometrics in the 21st Century. Hystrix, 24, 7-14. doi:10. 4404/hystrix-24.1-6283.

Anderson, M. J., \& Ter Braak, C. J. F. (2003). Permutation Tests for MultiFactoral Analysis of Variance. Journal of Statistical Computation and Simulation, 73, 85-113. doi:10.1080=0094965021000015558.

Arnold III, P. J. (1991). Dimensional Standardization and Production Scale in Mesoamerican Ceramics. Latin American Antiquity, 2, 363-370. URL: https://www.cambridge. org/core/journals/latin-american-antiquity/article/ dimensional-standardization-and-production-scale-in-mesoamerican-ceramics/ FB4BA60424201F66ABDFDB5F62617728. doi:10 . 2307/971784.

Banks, L. D., \& Winters, J. (1975). The Bentsen-Clark Site, Red River County, Texas: A Preliminary Report. San Antonio: Special Publication No. 2. Texas Archeological Society.

Bastir, M., \& Rosas, A. (2006). Correlated Variation between the Lateral Basicranium and the Face: A Geometric Morphometric Study in Different Human Groups. Archives of Oral Biology, 51, 814-24. URL: https://www. ncbi.nlm.nih.gov/pubmed/16681992. doi:10.1016/j. archoralbio. 2006. 03.009 . 
Bookstein, F. L. (1991). Morphometric Tools for Landmark Data: Geometry and Biology. Cambridge: Cambridge University Press.

Bookstein, F. L., Gunz, P., Mitterœcker, P., Prossinger, H., Schæfer, K., \& Seidler, H. (2003). Cranial Integration in Homo: Singular Warps Analysis of the Midsagittal Plane in Ontogeny and Evolution. Journal of Human Evolution, 44, 167-187. doi:10.1016/S0047-2484(02)00201-4.

Buchanan, B., \& Collard, M. (2010). A Geometric Morphometrics-Based Assessment of Blade Shape Differences among Paleoindian Projectile Point Types from Western North America. Journal of Archaeological Science, 37, 350-359. doi:10.1016/j.jas.2009.09.047.

Buchanan, B., Collard, M., Hamilton, M. J., \& O’Brien, M. J. (2011). Points and Prey: A Quantitative Test of the Hypothesis that Prey Size Influences early Paleoindian Projectile Point Form. Journal of Archaeological Science, 38, 852-864. doi:10.1016/j.jas.2010.11.007.

Byrne, F., Proffitt, T., Arroyo, A., \& de la Torre, I. (2016). A Comparative Analysis of Bipolar and Freehand Experimental Knapping Products from Olduvai Gorge, Tanzania. Quaternary International, 424, 58-68. doi:https://doi.org/10.1016/j.quaint.2015.08.018.

Cardillo, M. (2010). Some Applications of Geometric Morphometrics to Archaeology. In A. M. T. Elewa (Ed.), Morphometrics for Nonmorphometricians Lecture Notes in Earth Sciences (pp. 325-341). New York: Springer. doi:10 .1007/978-3-540-95853-6_15.

Charlin, J., \& González-José, R. (2012). Size and Shape Variation in Late Holocene Projectile Points of Southern Patagonia: A Geometric Morphometric Study. American Antiquity, 77, 221-242. doi:10.7183/0002-7316.77.2. 221.

${ }_{420}$ Collyer, M. L., \& Adams, D. C. (2007). Analysis of Two-State Multivariate 
Phenotypic Change in Ecological Studies. Ecology, 88, 683-692. URL: https:

//www.ncbi.nlm.nih.gov/pubmed/17503596. doi:10.1890/06-0727.

Collyer, M. L., \& Adams, D. C. (2013). Phenotypic Trajectory Analysis: Comparison of Shape Change Patterns in Evolution and Ecology. Hystrix, 24, 75-83. doi:doi:10.4404/hystrix-24.1-6298.

Collyer, M. L., Sekora, D. J., \& Adams, D. C. (2015). A Method for Analysis of Phenotypic Change for Phenotypes Described by High-Dimensional Data. Heredity, 115, 357-65. URL: http://www.ncbi.nlm.nih.gov/ pubmed/25204302. doi:10.1038/hdy.2014.75.

Corti, M. (1993). Geometric Morphometrics: An Extension of the Revolution. Trends in Ecology 85 Evolution, 8, 302-303. doi:https://doi.org/10.1016/ 0169-5347 (93) 90261-M.

Costin, C. L. (1991). Craft Specialization: Issues in Defining, Documenting, and Explaining the Organization of Production. In M. B. Schiffer (Ed.), ${ }_{435}$ Archaeological Method and Theory Vol. 3 (pp. 1-56). Tucson: University of Arizona Press.

Costin, C. L. (2001). Craft Production Systems. In G. M. Feinman, \& T. D. Price (Eds.), Archaeology at the Millennium: A Sourcebook (pp. 273-327). New York: Kluwar Academic/Plenum Press.

${ }_{440}$ Costin, C. L. (2005). Craft Production. In J. D. G. Maschner (Ed.), Handbook of Archaeological Methods (pp. 1034-1107). Walnut Creek: AltaMira.

Costin, C. L., \& Hagstrum, M. B. (1995). Standardization, Labor Investment, Skill, and the Organization of Ceramic Production in Late Prehispanic Highland Peru. American Antiquity, 60, 619-639. doi:10.2307/282046.

${ }_{445}$ Denton, J. T. (1983). Archaeological Testing of Site 41PK69 Polk County, Texas. Index of Texas Archaeology: Open Access Gray Literature from the Lone Star State, 1983, Report 23. doi:https://doi.org/10.21112/ita.1983.1.23. 
Eerkins, J. W., \& Bettinger, R. L. (2001). Techniques for Assessing Standardization in Artifact Assemblages: Can We Scale Material Variability? American Antiquity, 66, 493-504. doi:https://doi.org/10.2307/2694247.

Fox, A. N. (2015). A Study of Late Woodland Projectile Point Typology in New York using Elliptical Fourier Outline Analysis. Journal of Archaeological Science: Reports, 4, 501-509. doi:10.1016/j.jasrep.2015.10.022.

Gadus, E., Fields, R., \& Kibler, K. (2006). Data Recovery Excavations at 455 the J. B. White Site (41MM341), Milam County, Texas. Index of Texas Archaeology: Open Access Gray Literature from the Lone Star State, 2006, Report 10. doi:https://doi.org/10.21112/ita.2006.1.10.

Gero, J., \& Mazzullo, J. (1984). Analysis of Artifact Shape Using Fourier Series in Closed Form. Journal of Field Archaeology, 11, 315. doi:10.2307/529282.

${ }_{460}$ Gingerich, J. A. M., Sholts, S. B., Wärmländer, S. K. T. S., \& Stanford, D. (2014). Fluted Point Manufacture in Eastern North America: An Assessment of Form and Technology using Traditional Metrics and 3D Digital Morphometrics. World Archaeology, 46, 101-122. doi:10.1080/00438243.2014. 892437.

465 Goodall, C. (1991). Procrustes Methods in the Statistical Analysis of Shape. Journal of the Royal Statistical Society. Series B (Methodological), 53, 285339.

Gower, J. C. (1975). Generalized Procrustes Analysis. Psychometrika, 40, 33-51. doi:https://doi.org/10.1007/BF02291478.

470 Gunz, P., \& Harvati, K. (2007). The Neanderthal "Chignon": Variation, Integration, and Homology. Journal of Human Evolution, 52, 262-74. URL: https://www.ncbi.nlm.nih.gov/pubmed/17097133. doi:10.1016/j . jhevol.2006.08.010. 
Ioviţă, R. (2009). Ontogenetic Scaling and Lithic Systematics: Method and

Application. Journal of Archaeological Science, 36, 1447-1457. doi:10.1016/ j.jas.2009.02.008.

Ioviţă, R. (2010). Comparing Stone Tool Resharpening Trajectories with the Aid of Elliptical Fourier Analysis. In S. J. Lycett, \& P. Chauhan (Eds.), New Perspectives on Old Stones: Analytical Approaches to Pale-

480 olithic Technologies (pp. 235-253). New York: Springer-Verlag New York. doi:10.1007/978-1-4419-6861-6_10.

Ioviţă, R. (2011). Shape Variation in Aterian Tanged Tools and the Origins of Projectile Technology: A Morphometric Perspective on Stone Tool Function. PLoS One, 6, e29029. URL: http://www.ncbi.nlm.nih.gov/pubmed/ 22216161. doi:10.1371/journal.pone.0029029.

Ioviţă, R., \& McPherron, S. P. (2011). The Handaxe Reloaded: A Morphometric Reassessment of Acheulian and Middle Paleolithic Handaxes. Journal of Human Evolution, 61, 61-74. URL: http://www.ncbi.nlm.nih.gov/pubmed/ 21496877. doi:10.1016/j.jhevol.2011.02.007.

Jolliffe, I. T. (2002). Principal Component Analysis. New York: Springer.

Kendall, D. (1981). The Statistics of Shape. In V. Barnett (Ed.), Interpreting Multivariate Data (pp. 75-80). New York: Wiley.

Kendall, D. G. (1984). Shape Manifolds, Procrustean Metrics, and Complex Projective Spaces. Bulletin of the London Mathematical Society, 16, 81-121. doi:10.1112/blms/16.2.81.

Kenoyer, J. M., Vidale, M., \& Bhan, K. K. (1991). Contemporary Stone Beadmaking in Khambhat, India: Patterns of Craft Specialization and Organization of Production as Reflected in the Archaeological Record. World Archaeology, 23, 44-63. doi:https://doi.org/10.1080/00438243.1991.9980158.

500

Klingenberg, C. P. (2013). Visualizations in Geometric Morphometrics: How to Read and How to Make Graphs Showing Shape Changes. Hystrix, 
24, 15-24. URL: <GotoISI>://WOS:000330926000003. doi:http://dx.doi. org/10.4404/hystrix-24.1-7691.

Klingenberg, C. P., Barluenga, M., \& Meyer, A. (2002). Shape Analysis of Symmetric Structures: Quantifying Variation among Individuals and Asymmetry. Evolution, 56. doi:10.1554/0014-3820 (2002)056[1909: saossq]2 .0 .co;2.

Klingenberg, C. P., \& McIntyre, G. S. (1998). Geometric Morphometrics of Developmental Instability: Analyzing Patterns of Fluctuating Asymmetry with Procrustes Methods. Evolution, 52, 1363-1375. URL: https://www.ncbi.nlm.nih.gov/pubmed/28565401. doi:10.1111/j . 1558-5646.1998.tb02018.x.

Lycett, S. J. (2009). Quantifying Transitions: Morphometric Approaches to Palaeolithic Variability and Technological Change. In M. Camps, \& P. Chauhan (Eds.), Sourcebook of Paleolithic Transitions (pp. 79-92). Springer. doi:10.1007/978-0-387-76487-0_5.

Mardia, K. (2000). Statistical Assessment of Bilateral Symmetry of Shapes. Biometrika, 87, 285-300. doi:10.1093/biomet/87.2.285.

McClurkan, B. (1968). Livingston Reservoir, 1965-66: Late Archaic and NeoAmerican Occupations. The University of Texas at Austin, Texas Archeological Salvage Project, Paper No. 12.

Mitteroecker, P., \& Gunz, P. (2009). Advances in Geometric Morphometrics. Evolutionary Biology, 36, 235-247. doi:10.1007/s11692-009-9055-x.

Moore, C. B. (1912). Some Aboriginal Sites on Red River. Journal of the Academy of Natural Sciences of Philadelphia, 14, 526-636.

${ }_{525}$ Newell, H. P., \& Krieger, A. D. (1949). The George C. Davis Site, Cherokee County, Texas. Memoir No. 5, Menasha, Wisconsin: Society for American Archaeology. 
Quigg, M., Matchen, P., Ricklis, R., Gray, S., Frederick, C., \& Barrett, J. (2014). Eligibility Testing at Three Prehistoric Sites at Lynch Creek, Lampasas County, Texas. Index of Texas Archaeology: Open Access Gray Literature from the Lone Star State, 2014, Report 5. doi:https://doi.org/10. 21112/ita.2014.1.5.

R Core Development Team, (2017). R: A Language and Environment for Statistical Computing. R Foundation for Statistical Computing Vienna, Austria. URL: http://www.R-project.org/.

Ragan, K., \& Buchanan, B. (2018). Assessing Collector Bias: A Geometric Morphometric Analysis of a Collection of Isolated Clovis Points from the Midcontinent. Midcontinental Journal of Archaeology, 43, 91-111. doi:https : //doi.org/10.1080/01461109.2018.1426430.

Rezek, Z., Lin, S., Ioviţă, R., \& Dibble, H. L. (2011). The Relative Effects of Core Surface Morphology on Flake Shape and Other Attributes. Journal of Archaeological Science, 38, 1346-1359. doi:https://doi.org/10.1016/j . jas.2011.01.014.

Rice, P. M. (1991). Specialization, Standardization, and Diversity: A Retrospective. In R. L. Bishop, \& F. W. Lange (Eds.), The Ceramic Legacy of Anna O. Shepard (pp. 257-279). Niwot: University of Colorado Press.

Rohlf, F. J. (1999). Shape Statistics: Procrustes Superimpositions and Tangent Spaces. Journal of Classification, 16, 197-223. doi:10.1007/s003579900054.

Rohlf, F. J., \& Corti, M. (2000). Use of Two-Block Partial Least-Squares to Study Covariation in Shape. Systematic Biology, 49, 740-753. doi:10.1080/ 106351500750049806.

Rohlf, F. J., \& Slice, D. (1990). Extensions of the Procrustes Method for the Optimal Superimposition of Landmarks. Systematic Zoology, 39, 40-59. doi:10.2307/2992207. 
Selden Jr., R. Z. (2018a). A Preliminary Study of Smithport Plain Bottle Morphology in the Southern Caddo Area. Bulletin of the Texas Archeological Society, 89, (in press).

Selden Jr., R. Z. (2018b). Ceramic Morphological Organisation in the Southern Caddo Area: The Clarence H. Webb Collections. Journal of Cultural Her${ }_{560}$ itage, (in press). doi:https://doi.org/10.1016/j.culher.2018.07.002.

Shafer, H. J. (1973). Lithic Technology at the George C. Davis Site, Cherokee County, Texas. Unpublished PhD Dissertation, The University of Texas at Austin.

Shafer, H. J. (2006). People of the Prairie: A Possible Connection to the Davis Site Caddo. Texas Department of Transportation and Prewitt and Associates, Inc., Austin.

Sherratt, E., Gower, D. J., Klingenberg, C. P., \& Wilkinson, M. (2014). Evolution of Cranial Shape in Caecilians (Amphibia: Gymnophiona). Evolutionary Biology, 41, 528-545. URL: <GotoISI>://WOS:000344862900003. doi:https://doi.org/10.1007/s11692-014-9287-2.

Sholts, S. B., Stanford, D. J., Flores, L. M., \& Wärmländer, S. K. T. S. (2012). Flake Scar Patterns of Clovis Points Analyzed with a New Digital Morphometrics Approach: Evidence for Direct Transmission of Technological Knowledge across Early North America. Journal of Archaeological Science, 39, 3018-3026. doi:10.1016/j.jas.2012.04.049.

Shott, M. J. (2005). The Reduction Thesis and its Discontents: Overview of the Volume. In C. Clarkson, \& L. Lamb (Eds.), Rocking the Boat: Recent Australian Approaches to Lithic Reduction, Use and Classification. (pp. 109125). Oxford: British Archaeological Reports International Series.

Sinopoli, C. M. (1988). The Organization of Craft Production at Vijayanagara, South India. American Anthropologist, 90, 580-597. doi:https://doi.org/ 10.1525/aa.1988.90.3.02a00040. 
Slice, D. E. (2001). Landmark Coordinates Aligned by Procrustes Analysis Do Not Lie in Kendall's Shape Space. Systematic Biology, 50, 141-149. doi:10.1080/10635150119110.

Smith, H. L. (2010). A Behavioral Analysis of Clovis Point Morphology using Geometric Morphometrics. Thesis.

Smith, H. L., \& DeWitt, T. J. (2016). The Northern Fluted Point Complex: Technological and Morphological Evidence of Adaptation and Risk in the Late Pleistocene-Early Holocene Arctic. Archaeological and Anthropological Sciences, . doi:DOI10.1007/s12520-016-0335-y.

Smith, H. L., Smallwood, A. M., \& DeWitt, T. J. (2014). A Geometric Morphometric Exploration of Clovis Fluted-Point Shape Variability. In A. M. Smallwood, \& T. A. Jennings (Eds.), Clovis: On the Edge of a New Understanding (pp. 161-180). College Station: Texas A\&M University Press.

Thulman, D. K. (2012). Discriminating Paleoindian Point Types from Florida using Landmark Geometric Morphometrics. Journal of Archaeological Science, 39, 1599-1607. doi:10.1016/j.jas.2012.01.004.

Turner, E. S., Hester, T. R., \& McReynolds, R. L. (2011). Stone Artifacts of Texas Indians. Lanham, Maryland: Third Edition. Taylor Trade Publishing.

Webb, C. H., \& Dodd, J., M. (1939). Further Excavations of the Gahagan Mound: Connections with a Florida Culture. Bulletin of the Texas Archeological and Paleontological Society, 11, 92-126.

Webb, C. H., \& McKinney, R. R. (1975). Mounds Plantation (16CD12), Caddo 605 Parish, Louisiana. Louisiana Archaeology, 2, 39-128.

Webb, W. S., \& DeJarnette, D. L. (1942). An Archaeological Survey of Pickwick Basin in the Adjacent Portions of the States of Alabama, Mississippi, and Tennessee. Bureau of American Ethnology, Washington, D. C. 
Wilczek, J., Monna, F., Gabillot, M., Navarro, N., Rusch, L., \& Chateau, C. (2015). Unsupervised Model-Based Clustering for Typological Classification of Middle Bronze Age Flanged Axes. Journal of Archaeological Science: Reports, 3, 381-391. doi:https://doi.org/10.1016/j.jasrep.2015.06.030.

Wold, H. (1966). Estimation of Principal Components and Related Models by Iterative Least Squares. In R. Krishnaiaah (Ed.), Multivariate Analysis (pp. 391-420). New York: Academic Press.

Zelditch, M. L., Swiderski, D. L., Sheets, H. D., \& Fink, W. L. (2004). Geometric Morphometrics for Biologists : A Primer. Burlington: Elsevier Science. URL: http://ebookcentral.proquest.com/lib/tamucs/detail. action? doc ID $=298308$. 